\title{
Cytotoxic Arylnaphthalene Lignans from Phyllanthus oligospermus
}

\author{
Shwu-Jen $\mathrm{WU}^{*, a}$ and Tian-Shung $\mathrm{Wu}^{b, c}$ \\ ${ }^{a}$ Department of Medical Technology, Chung Hwa College of Medical Technology; Tainan Hsien 717, Taiwan: \\ ${ }^{b}$ Department of Chemistry, National Cheng Kung University; Tainan 701, Taiwan: and ${ }^{c}$ National Research Institute of \\ Chinese Medicine; Taipei 112, Taiwan, Republic of China. $\quad$ Received March 14, 2006; accepted May 22, 2006
}

\begin{abstract}
Three new arylnaphthalene lignans, namely phyllanthusmins $\mathrm{A}-\mathrm{C}$, together with nine known compounds were isolated and characterized from the stems and roots of Phyllanthus oligospermus by a bioassay-guided purification. The structures of the new compounds were elucidated by means of spectroscopic data interpretation. Among them, phyllanthusmin A displayed significant cytotoxicity against KB and P-388 cancer cell lines.
\end{abstract}

Key words Phyllanthus oligospermus; Euphorbiaceae; arylnaphthalene lignan; phyllanthusmin

Plants of the genus Phyllanthus are part of one of the largest families of higher plants the Euphorbiaceae. Phyllanthus contains more than 600 species widely distributed throughout South America, Asia and Africa. Of which Phyllanthus oligospermus a shrub, is one of the most common species found in Taiwan. ${ }^{1)}$ Members of Phyllanthus have been reported to produce terpenes, ${ }^{2,3)}$ alkaloids, ${ }^{4,5)}$ lignans, ${ }^{6-8)}$ flavonoids, ${ }^{9,10)}$ and tannins ${ }^{11,12)}$ with diverse biological activities including inhibition of hepatitis B virus, hypoglycemic, hypotensive and diuretic effects and antinociceptive, antitumor, antioxidant, and antiinflammatory properties. Many species of this genus have long been used in the traditional Chinese medicine for the treatment of eye disease, jaundice, headache, eczema, warts, diarrhea, diabetes, hepatitis and dropsy for liver protection and as diuretic. ${ }^{13)}$

The use of cytotoxicity test as a bioassay-guided method for screening plant extracts showed that the $\mathrm{CHCl}_{3}$ solubles of $\mathrm{MeOH}$ extract of the stems and roots of this plant caused significant inhibition against KB and P-388 cell lines. The $\mathrm{CHCl}_{3}$ extract was chosen therefore for further investigation.

Bioassay directed fractionation of this extract provided three new arylnaphthalene lignans named phyllanthusmins A $-\mathrm{C}(\mathbf{1}-\mathbf{3})$. In this paper, we report the structural elucidation of these compounds together with their cytotoxic evaluation. We also describe the isolation of nine known compounds including three lignans, justicidin-A (4) ${ }^{14)}$ diphyllin $(5)^{14)}$ and haplomyrtin $(\mathbf{6}),{ }^{15)}$ four benzenoids, methyl vanillate (7), ${ }^{16)}$ vanillin $(\mathbf{8}),{ }^{16)} 3$,4-dimethoxybenzoic acid $(9),{ }^{17)}$ methyl ferulate (10), ${ }^{18)}$ and two steroids, $\beta$-sitosterol $(\mathbf{1 1})^{19)}$ and $\beta$-sitosteryl glucoside (12). ${ }^{19)}$

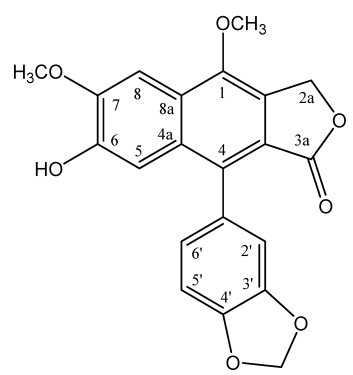

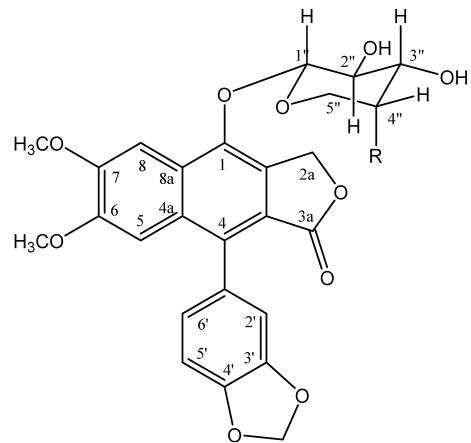

$2 \mathrm{R}=\mathrm{OCOCH}_{3}$

$3 \mathrm{R}=\mathrm{OH}$

\section{Results and Discussion}

The air dried stems and roots of $P$. oligospermus were extracted with $\mathrm{MeOH}$ and the obtained extract was partitioned with $n$-hexane, $\mathrm{CHCl}_{3}, n$ - $\mathrm{BuOH}$ and $\mathrm{H}_{2} \mathrm{O}$, successively. $\mathrm{Pu}$ rification of $\mathrm{CHCl}_{3}$ solubles by a series of chromatography over silica gel resulted in isolation of three new lignans and nine known compounds. The structures of known compounds were determined by comparison with literature data.

Phyllanthusmin A (1) was obtained as colorless needles. Its molecular formula was determined as $\mathrm{C}_{21} \mathrm{H}_{16} \mathrm{O}_{7}$ by $\mathrm{HR}$ EI-MS. The UV absorption maxima and IR absorption bands at 3450 and $1763 \mathrm{~cm}^{-1}$ for a hydroxyl group and $\alpha, \beta$-unsaturated $\gamma$-lactone, respectively, were similar with those of arylnaphthalene type lignans, justicidin-A (4) ${ }^{14)}$ diphyllin (5), ${ }^{14)}$ and haplomyrtin (6). ${ }^{15)}$ The ${ }^{13} \mathrm{C}$-NMR signals of $\mathbf{1}$ were also identical with those of diphyllin $(\mathbf{5})$ and haplomyrtin $(\mathbf{6})^{20)}$ indicated the presence of arylnaphthalene lignan basic skeleton in $\mathbf{1}$. The general appearance of ${ }^{1} \mathrm{H}-\mathrm{NMR}$ spectrum was also in good agreement with that of haplomyrtin (6), with the exception of having two methoxy signals at $\delta_{\mathrm{H}} 4.09(3 \mathrm{H}, \mathrm{s})$ and $\delta_{\mathrm{H}} 4.13(3 \mathrm{H}, \mathrm{s})$ instead of one, as in the case of haplomyrtin $(6)$. The aromatic proton $\mathrm{ABX}$ system $\left[\delta_{\mathrm{H}} 6.76(1 \mathrm{H}\right.$, d, $\left.J=7.7 \mathrm{~Hz}), \delta_{\mathrm{H}} 6.78(1 \mathrm{H}, \mathrm{s}), \delta_{\mathrm{H}} 6.94(1 \mathrm{H}, \mathrm{d}, J=7.7 \mathrm{~Hz})\right]$ and two one proton signals $\left[\delta_{\mathrm{H}} 7.21(1 \mathrm{H}, \mathrm{s}), \delta_{\mathrm{H}} 7.56(1 \mathrm{H}, \mathrm{s})\right]$. It is also supported by the EI-MS spectrum, which showed the $[\mathrm{M}]^{+}$at $m / z$ 380, 14 amu more than the corresponding mass of haplomyrtin (6). The ${ }^{1} \mathrm{H}-\mathrm{NMR}$ spectrum also contained an exchangeable singlet at $\delta_{\mathrm{H}} 5.94$ assigned for hydroxyl group. The ${ }^{1} \mathrm{H}-{ }^{1} \mathrm{H}$ NOESY experiment of 1 (Fig. 1) showed that a methoxy group at $\delta_{\mathrm{H}} 4.13(3 \mathrm{H}, \mathrm{s})$ had correlation with methylene protons of the lactone ring at $\delta_{\mathrm{H}} 5.54$ $(2 \mathrm{H}, \mathrm{s})$, while the other methoxy group at $\delta_{\mathrm{H}} 4.09(3 \mathrm{H}, \mathrm{s})$ showed correlation with $\mathrm{H}-8\left[\delta_{\mathrm{H}} 7.56(1 \mathrm{H}, \mathrm{s})\right]$, which indicated that the methoxy groups were linked to C-1 and C-7, respectively. Thus, hydroxyl group $\left(\delta_{\mathrm{H}} 5.94\right)$ is located at C6 . These spectral data established the structure of phyllanthusmin A as shown.

Phyllanthusmin B (2) was obtained as colorless prisms. $[\alpha]_{\mathrm{D}}-21.0^{\circ}(\mathrm{MeOH})$. The UV spectral behaviour and hydroxyl and ester absorption bands in IR suggested an arylnaphthalene skeleton for 2. A molecular-related ion peak at $m / z 555.1502[\mathrm{M}+1]^{+}$in HR-FAB-MS corresponding to the molecular formula $\mathrm{C}_{28} \mathrm{H}_{26} \mathrm{O}_{12}$. The ${ }^{1} \mathrm{H}-\mathrm{NMR}$ spectrum indicated the presence of two singlet aromatic protons for $\mathrm{H}-5$ $\left(\delta_{\mathrm{H}} 6.98\right)$ and $\mathrm{H}-8\left(\delta_{\mathrm{H}} 8.16\right)$ and an $\mathrm{ABX}\left[\delta_{\mathrm{H}} 6.78(1 \mathrm{H}, \mathrm{dd})\right.$, 


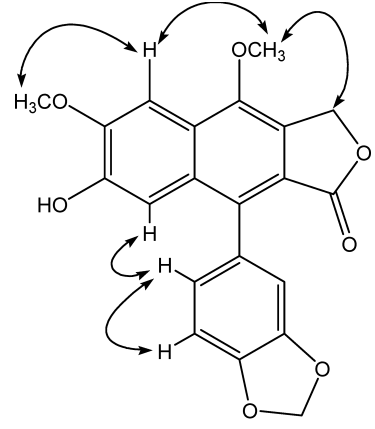

1

Fig. 1. NOESY Correlation of $\mathbf{1}$

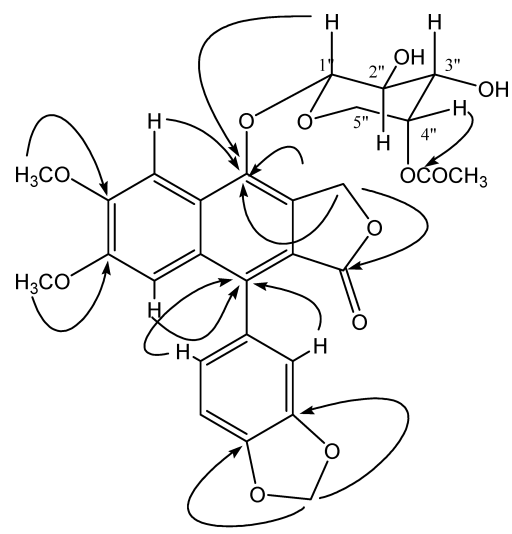

2

Fig. 2. Major HMBC Correlation of $\mathbf{2}$

$\left.\delta_{\mathrm{H}} 6.92(1 \mathrm{H}, \mathrm{d}), \delta_{\mathrm{H}} 7.03(1 \mathrm{H}, \mathrm{d})\right]$ system corresponding to the three ring $\mathrm{C}$ protons. The identities of substitutes were easily discernable from the signals of methylenedioxy group at $\delta_{\mathrm{H}} 6.12(2 \mathrm{H}, \mathrm{s})$ and two methoxy groups at $\delta_{\mathrm{H}} 3.66(3 \mathrm{H}, \mathrm{s})$ and $\delta_{\mathrm{H}} 3.94(3 \mathrm{H}, \mathrm{s})$. The ${ }^{1} \mathrm{H}-\mathrm{NMR}$ assignments were confirmed by HMQC, HMBC, COSY and ROESY experiments. Thus, this established the precise identity of aglycone as diphyllin (5). The doublet at $\delta_{\mathrm{H}} 4.81$ with a coupling constant $J_{1^{\prime \prime}, 2^{\prime \prime}}=6.7 \mathrm{~Hz}$ indicated the presence of anomeric proton in an axial orientation. A coupling constant of $J_{2^{\prime \prime}, 3^{\prime \prime}}=9.2 \mathrm{~Hz}$ implied that $\mathrm{H}-2^{\prime \prime}\left(\delta_{\mathrm{H}} 3.77\right)$ and $\mathrm{H}-3^{\prime \prime}\left(\delta_{\mathrm{H}} 3.69\right)$ were also axial. The hemiacetal linkage was therefore equatorial. The appearance of H-4" $\left(\delta_{\mathrm{H}} 4.98\right)$ in the ${ }^{1} \mathrm{H}-\mathrm{NMR}$ spectrum as a broad singlet suggesting that $\mathrm{H}-4^{\prime \prime}$ was equatorial relative to $\mathrm{H}-3^{\prime \prime}$ and $\mathrm{H}-5^{\prime \prime}$, while the signals at $\delta_{\mathrm{H}} 3.63$ and $\delta_{\mathrm{H}} 3.86$ $\left(J_{\mathrm{gem}}=12.4 \mathrm{~Hz}\right)$ were pointed to the presence of oxygenated methylene group. Moreover an acetyl methyl group at $\delta_{\mathrm{H}}$ $2.09(3 \mathrm{H}, \mathrm{s})$ in ${ }^{1} \mathrm{H}-\mathrm{NMR}$ and corresponding carbon signal at $\delta_{\mathrm{C}} 21.2$, in addition to a carbonyl at $\delta_{\mathrm{C}} 170.2$ in ${ }^{13} \mathrm{C}$-NMR indicated the presence of an acetyl group. The downfield shift of $\mathrm{H}-4$ " and the HMBC correlation between the H-4" of arabinose and an acetyl carbon inferred the attachment acetyl group to C-4", HMBC spectrum also showed a long range correlation between anomeric proton at $\delta_{\mathrm{H}} 4.81$ and a carbon at $\delta_{\mathrm{C}} 144.8(\mathrm{C}-1)$ (Fig. 2). In the FAB-MS spectrum the molecular ion at $\mathrm{m} / z 555[\mathrm{M}+1]^{+}$and a significant fragment at $\mathrm{m} / \mathrm{z} 380$ due to the loss of one acetyl arabinose were consistent with these assignments. Thus, the structure $\mathbf{2}$ assigned

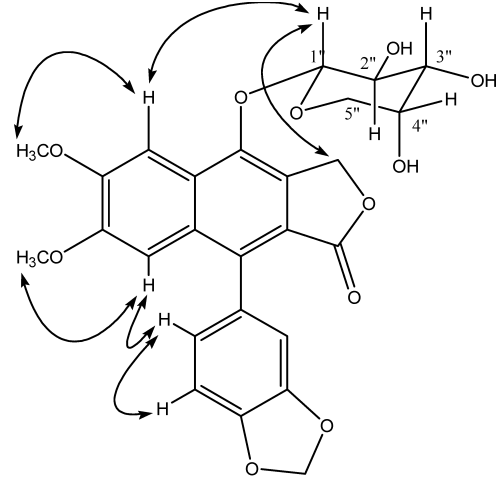

3

Fig. 3. Major ROESY Correlation of $\mathbf{3}$

for phyllamthusmin B

Phyllanthusmin $\mathrm{C}$ (3) was obtained as colorless prisms, $[\alpha]_{\mathrm{D}}-23.3^{\circ}(\mathrm{MeOH})$. The UV, IR and ${ }^{1} \mathrm{H}-\mathrm{NMR}$ spectra of $\mathbf{3}$ showed close resemblance with $\mathbf{2}$, suggesting a similar arylnaphthalene lignan skeleton for 3. Pseudomolecular ion at $513.1396[\mathrm{M}+1]^{+}$in HR-FAB-MS, corresponds to the molecular formula $\mathrm{C}_{26} \mathrm{H}_{24} \mathrm{O}_{11}$ and a significant peak at $\mathrm{m} / \mathrm{z} 380$ $[\mathrm{M}-132]^{+}$due to loss of sugar moiety indicating the presence of a pentose moiety, thus defining $\mathbf{3}$ as a glycoside. The splitting pattern and coupling constants of the sugar protons in $\mathbf{3}$ were very similar to those of $\mathbf{2}$, suggesting the presence of arabinose residue in 3 . However, absence of acetyl group signals and the appearance of $[\mathrm{M}]^{+}$at $\mathrm{m} / z$ 512, $43 \mathrm{amu}$ less than that of $\mathbf{2}$, suggesting the presence of an arabinose moiety instead of a mono- $O$-acetyl arabinose moiety. The lack of carbonyl absorption in the IR spectrum, 21 carbon signals due to the diphyllin (5) moiety and 5 signals due to arabinose in the ${ }^{13} \mathrm{C}$-NMR spectrum of $\mathbf{3}$ also favored the proposal. The comparison of the ${ }^{13} \mathrm{C}$-NMR chemical shifts of the sugar moiety of $\mathbf{3}$ with those of known sugar conclusively confirmed the presence of the arabinopyranose unit in $3 .^{21)}$ Furthermore, a ${ }^{1} \mathrm{H}-{ }^{1} \mathrm{H}$ ROESY experiment with the phyllanthus$\min \mathrm{C}(3)$ (Fig. 3) was conducted. On the basis of these observations the structure of phyllanthusmin $\mathrm{C}$ was established as 3 .

The cytotoxic activities of compounds 1, 2, 4 and 5 were subjected to evaluate their cytotoxicity. Phyllanthusmin A (1) showed significant cytotoxicity against KB and P-388 with $\mathrm{IC}_{50}$ values of 2.24 and $0.13 \mu \mathrm{g} / \mathrm{ml}$, respectively.

\section{Experimental}

General Procedures Melting points were measured on a Yanagimoto MP-S3 micro melting point apparatus and are uncorrected. Optical rotations were recorded using a JASCO DIP 370 digital polarimeter. The UV spectra were recorded on a Hitachi UV-3210 spectrophotometer in $\mathrm{MeOH}$ solution. The IR spectra were measured on a Shimadzu FTIR-8501 spectrophotometer as $\mathrm{KBr}$ disks. The ${ }^{1} \mathrm{H}-\mathrm{NMR}(400 \mathrm{MHz})$ and ${ }^{13} \mathrm{C}-\mathrm{NMR}(100 \mathrm{MHz})$ spectra were recorded on a Varian-400 Unity Plus spectrometer. Chemical shifts are shown in $\delta$ values with tetramethylsilane as an internal reference. The mass spectra (EI or FAB) were performed on a VG 70-250S spectrometer.

Plant Material The dried stems and roots of $P$. oligospermus HaYATA were collected from Tainan Hsien, Taiwan in February 1995 and verified by Prof. C.-S. Kouh Department of Life Science, National Cheng Kung University, Taiwan. Voucher specimens were deposited in the Herbarium of National Cheng-Kung University, Tainan, Taiwan.

Extraction and Separation The dried stems and roots of P. oligospermus $13.64 \mathrm{~kg}$ were extracted with $\mathrm{MeOH}(\times 5)$ and concentrated to give to 
brownish syrup (912.3 g). This extract was suspended in $\mathrm{H}_{2} \mathrm{O}$ and partitioned with $\mathrm{CHCl}_{3}$ and $n$-BuOH successively. The $\mathrm{CHCl}_{3}$ fraction was defatted with $n$-hexane. The $\mathrm{CHCl}_{3}$ extract $(30 \mathrm{~g})$ was chromatographed directly on silica gel column and eluted with gradients of $\mathrm{CHCl}_{3}-\mathrm{MeOH}$ to afford 5 frs. Fraction 1 was rechromatographed on silica gel and eluted with $n$ hexane-EtOAc $(15: 1)$ to give $7(3 \mathrm{mg})$. Fraction 2 was rechromatographed on silica gel with $\mathrm{C}_{6} \mathrm{H}_{6}-$ EtOAc $(9: 1)$ as eluent to afford $8(5.1 \mathrm{mg}), 4$ $(3.2 \mathrm{mg})$. Fraction 3 was rechromatographed on silica gel and eluted with $\mathrm{C}_{6} \mathrm{H}_{6}-\mathrm{Me}_{2} \mathrm{CO}$ to yield $\mathbf{8}(10.2 \mathrm{mg}), \mathbf{5}(3.7 \mathrm{mg}), \mathbf{1}(8 \mathrm{mg})$. Fraction 4 was purified by silica gel column chromatography and eluted with $\mathrm{CHCl}_{3}-\mathrm{Me}_{2} \mathrm{CO}$ (9:1) followed by TLC with $\mathrm{CHCl}_{3}-\mathrm{Me}_{2} \mathrm{CO}(7: 1)$ to give $6(4.5 \mathrm{mg}), 9$ $(3.1 \mathrm{mg}), \mathbf{1 0}(5.4 \mathrm{mg})$. Fraction 5 was separated by silica gel column chromatography and using $\mathrm{CHCl}_{3}-\mathrm{Me}_{2} \mathrm{CO}(5: 1)$ as eluent to give $2(5.6 \mathrm{mg}), 3$ (2.1 mg), 11 (13.2 mg), 12 (36.1 mg)

Phyllanthuspermin A (1): Colorless needles $(\mathrm{MeOH}), \mathrm{mp} 283-284^{\circ} \mathrm{C}$, HR-EI-MS: found [M] ${ }^{+} 380.0839 ; \mathrm{C}_{21} \mathrm{H}_{16} \mathrm{O}_{7}$, requires 380.0896; EI-MS $\mathrm{m} / \mathrm{z}$ (rel. int.): $380\left(100,[\mathrm{M}]^{+}\right), 365(5), 349(5), 337$ (7), 307 (9), 279 (16), 216 (15); UV $\lambda_{\text {max }}(\mathrm{MeOH}) \mathrm{nm}(\log \varepsilon): 230$ (4.29), 263 (4.61), 292 (3.93), 310 (3.64) sh, 356 (3.64); IR $v_{\max }(\mathrm{KBr}) \mathrm{cm}^{-1}: 3450,1763,1620,1600,930 ;{ }^{1} \mathrm{H}$ NMR $\left(\mathrm{CDCl}_{3}, 400 \mathrm{MHz}\right) \delta: 4.09\left(3 \mathrm{H}, \mathrm{s}, 7-\mathrm{OCH}_{3}\right), 4.13\left(3 \mathrm{H}, \mathrm{s}, 1-\mathrm{OCH}_{3}\right)$, $5.54(2 \mathrm{H}, \mathrm{s}, \mathrm{H}-2 \mathrm{a}), 5.94\left(1 \mathrm{H}, \mathrm{s}, \mathrm{D}_{2} \mathrm{O}\right.$ exchange disap., $\left.\mathrm{OH}\right), 6.04,6.06$ (each $\left.1 \mathrm{H}, \mathrm{s}, \mathrm{OCH}_{2} \mathrm{O}\right), 6.76\left(1 \mathrm{H}, \mathrm{d}, J=7.7 \mathrm{~Hz}, \mathrm{H}-6^{\prime}\right), 6.78\left(1 \mathrm{H}, \mathrm{s}, \mathrm{H}-2^{\prime}\right), 6.94(1 \mathrm{H}$, d, $\left.J=7.7 \mathrm{~Hz}, \mathrm{H}-5^{\prime}\right), 7.21(1 \mathrm{H}, \mathrm{s}, \mathrm{H}-5), 7.56(1 \mathrm{H}, \mathrm{s}, \mathrm{H}-8) ;{ }^{13} \mathrm{C}-\mathrm{NMR}\left(\mathrm{CDCl}_{3}\right.$, $100 \mathrm{MHz}) \delta: 169.6$ (C-3a), 149.3 (C-1), 147.9 ( C-7), 147.4 (C-3'), 146.6 (C-6), 144.9 (C-4'), 134.6 (C-4), 131.2 (C-1'), 128.4 (C-4a), 125.7 (C-3) 123.8 (C-8a), 123.7 (C-6'), 119.4 (C-2), $110.8\left(\mathrm{C}-2^{\prime}\right), 109.8\left(\mathrm{C}-5^{\prime}\right), 108.2$ $(\mathrm{C}-5), 101.1\left(\mathrm{OCH}_{2} \mathrm{O}\right), 100.2(\mathrm{C}-8), 66.6(\mathrm{C}-2 \mathrm{a}), 59.6\left(\mathrm{OCH}_{3}\right), 56.2\left(\mathrm{OCH}_{3}\right)$

Phyllanthuspermin B (2): Colorless prisms $(\mathrm{MeOH}), \mathrm{mp} 253-255^{\circ} \mathrm{C}$, $[\alpha]_{\mathrm{D}}-21.0^{\circ}(c=0.035, \mathrm{MeOH}) ;$ HR-FAB-MS $\mathrm{m} / \mathrm{z} 555.1502(\mathrm{M}+1)^{+}$ (Calcd for $\mathrm{C}_{28} \mathrm{H}_{26} \mathrm{O}_{12}, 555.1501$ ); FAB-MS $m / z$ (rel. int.): $555[\mathrm{M}+1]^{+}, 380$ (6), 307 (25), 290 (12), 177 (10), 155 (29), 154 (100), 152 (11), 139 (19) 137 (68); UV $\lambda_{\max }(\mathrm{MeOH}) \mathrm{nm}(\log \varepsilon): 261$ (3.74), 298 (3.17), 315 (3.02), 347 (2.64); IR $v_{\max }(\mathrm{KBr}) \mathrm{cm}^{-1}: 3392,1734,1622,930$; ${ }^{1} \mathrm{H}-\mathrm{NMR}$ (DMSO$\left.d_{6}, 400 \mathrm{MHz}\right) \delta: 2.09\left(3 \mathrm{H}, \mathrm{s}, \mathrm{OCOCH}_{3}\right), 3.63(1 \mathrm{H}, \mathrm{brd}, J=12.4 \mathrm{~Hz}, \mathrm{H}-$ $5^{\prime \prime}$ eq. $), 3.66\left(3 \mathrm{H}, \mathrm{s}, 6-\mathrm{OCH}_{3}\right), 3.69\left(1 \mathrm{H}, \mathrm{dd}, J=9.2,3.8 \mathrm{~Hz}, \mathrm{H}-3^{\prime \prime}\right), 3.77(1 \mathrm{H}$ dd, $\left.J=9.2,6.7 \mathrm{~Hz}, \mathrm{H}-2^{\prime \prime}\right), 3.86\left(1 \mathrm{H}, \mathrm{dd}, J=12.4,2.4 \mathrm{~Hz}, \mathrm{H}-5^{\prime \prime}\right.$ ax. $), 3.94(3 \mathrm{H}$, s, 7- $\left.-\mathrm{OCH}_{3}\right), 4.81\left(\mathrm{H}, \mathrm{d}, J=6.7 \mathrm{~Hz}, \mathrm{H}-1^{\prime \prime}\right), 4.98(1 \mathrm{H}$, br s, H-4"), $5.36(1 \mathrm{H}$, brd, $\left.J=4.9 \mathrm{~Hz}, 3^{\prime \prime}-\mathrm{OH}\right), 5.46(1 \mathrm{H}, \mathrm{d}, J=15.1 \mathrm{~Hz}, \mathrm{H}-2 \mathrm{a}), 5.51(1 \mathrm{H}, \mathrm{d}$, $J=15.1 \mathrm{~Hz}, \mathrm{H}-2 \mathrm{~b}), 5.99\left(1 \mathrm{H}\right.$, br d, $\left.J=4.9 \mathrm{~Hz}, 2^{\prime \prime}-\mathrm{OH},\right), 6.12\left(2 \mathrm{H}, \mathrm{s}, \mathrm{OCH}_{2} \mathrm{O}\right)$, $6.78\left(1 \mathrm{H}, \mathrm{dd}, J=7.9,3.0 \mathrm{~Hz}, \mathrm{H}-6^{\prime}\right), 6.92\left(1 \mathrm{H}, \mathrm{d}, J=3.0 \mathrm{~Hz}, \mathrm{H}-2^{\prime}\right), 6.98(1 \mathrm{H}$, $\mathrm{s}, \mathrm{H}-5), 7.03\left(1 \mathrm{H}, \mathrm{d}, J=7.9 \mathrm{~Hz}, \mathrm{H}-5^{\prime}\right), 8.16(1 \mathrm{H}, \mathrm{s}, \mathrm{H}-8) .{ }^{13} \mathrm{C}-\mathrm{NMR}$ (DMSO$\left.d_{6}, 100 \mathrm{MHz}\right) \delta: 170.2\left(\mathrm{CH}_{3} \mathrm{CO}\right), 169.2(\mathrm{C}-3 \mathrm{a}), 151.6(\mathrm{C}-7), 150.1(\mathrm{C}-6)$, 147.1 (C-3', 4'), 144.8 (C-1), 135.0 (C-4), 129.9 (C-4a), 129.4 (C-3), 128.3 (C-1'), 126.7 (C-8a), 123.7 (C-6'), 118.9 (C-2), 111.0 (C-2'), 108.1 (C-5'), $105.6(\mathrm{C}-5), 105.2\left(\mathrm{C}-1^{\prime \prime}\right), 101.9(\mathrm{C}-8), 101.3\left(\mathrm{OCH}_{2} \mathrm{O}\right), 71.3\left(\mathrm{C}-2^{\prime \prime}\right), 70.8$ $\left(\mathrm{C}-4^{\prime \prime}\right), 70.5\left(\mathrm{C}-3^{\prime \prime}\right), 67.2(\mathrm{C}-2 \mathrm{a}), 63.8\left(\mathrm{C}-5^{\prime \prime}\right), 56.0\left(7-\mathrm{OCH}_{3}\right), 55.4\left(6-\mathrm{OCH}_{3}\right)$, $21.2\left(\mathrm{CH}_{3} \mathrm{CO}\right)$

Phyllanthuspermin C (3): Colorless prisms $(\mathrm{MeOH}), \mathrm{mp} 247-249^{\circ} \mathrm{C}$, $[\alpha]_{\mathrm{D}}-23.3^{\circ}(c=0.015, \mathrm{MeOH})$; HR-FAB-MS $\mathrm{m} / \mathrm{z} 513.1396[\mathrm{M}+1]^{+}$ (Calcd for $\left.\mathrm{C}_{26} \mathrm{H}_{24} \mathrm{O}_{11}, 513.1392\right)$; FAB-MS $m / z$ (rel. int.): [513 (M+1) ${ }^{+}$(4)], 387 (16), 386 (50), 380 (10), 371 (24), 309 (19), 293 (21); UV $\lambda_{\max }(\mathrm{MeOH})$ $\mathrm{nm}(\log \varepsilon)$ : 261 (4.27), 292 (3.89), 310 (3.97), 353 (3.67); IR $v_{\max }(\mathrm{KBr})$ $\mathrm{cm}^{-1}: 3526,1741,1627,930 ;{ }^{1} \mathrm{H}-\mathrm{NMR}\left(\mathrm{CDCl}_{3}, 400 \mathrm{MHz}\right) \delta: 2.50,2.67$, 3.02 (each $1 \mathrm{H}$, brs, $\mathrm{D}_{2} \mathrm{O}$ exchange disap., $\left.\mathrm{OH}\right), 3.51(1 \mathrm{H}, \mathrm{dd}, J=12.8$, $2.8 \mathrm{~Hz}, \mathrm{H}-5^{\prime \prime}$ eq.), $3.68\left(1 \mathrm{H}, \mathrm{dd}, J=8.0,7.6 \mathrm{~Hz}, \mathrm{H}-2^{\prime \prime}\right), 3.81\left(3 \mathrm{H}, \mathrm{s}, 6-\mathrm{OCH}_{3}\right)$, $4.00(1 \mathrm{H}$, br s, H-4" $), 4.05\left(3 \mathrm{H}, \mathrm{s}, 7-\mathrm{OCH}_{3}\right), 4.08(1 \mathrm{H}, \mathrm{d}, J=12.8 \mathrm{~Hz}, \mathrm{H}-$ $5^{\prime \prime}$ ax.), $4.10\left(1 \mathrm{H}, \mathrm{dd}, J=7.6,3.2 \mathrm{~Hz}, \mathrm{H}-3^{\prime \prime}\right), 4.76\left(1 \mathrm{H}, \mathrm{d}, J=8.0 \mathrm{~Hz}, \mathrm{H}-1^{\prime \prime}\right)$, $5.43(1 \mathrm{H}, \mathrm{d}, J=15.3 \mathrm{~Hz}, \mathrm{H}-2 \mathrm{a}), 5.55(1 \mathrm{H}, \mathrm{d}, J=15.3 \mathrm{~Hz}, \mathrm{H}-2 \mathrm{~b}), 6.08,6.09$ (each $\left.1 \mathrm{H}, \mathrm{s}, \mathrm{OCH}_{2} \mathrm{O}\right), 6.81\left(1 \mathrm{H}, \mathrm{dd}, J=8.2,1.4 \mathrm{~Hz}, \mathrm{H}-6^{\prime}\right), 6.84(1 \mathrm{H}, \mathrm{d}$, $\left.J=1.4 \mathrm{~Hz}, \mathrm{H}-2^{\prime}\right), 6.96\left(1 \mathrm{H}, \mathrm{d}, J=8.2 \mathrm{~Hz}, \mathrm{H}-5^{\prime}\right), 7.09(1 \mathrm{H}, \mathrm{s}, \mathrm{H}-5), 792(1 \mathrm{H}$, $\mathrm{s}, \mathrm{H}-8) ;{ }^{13} \mathrm{C}-\mathrm{NMR}\left(\mathrm{CDCl}_{3}, 100 \mathrm{MHz}\right) \delta: 172.2$ (C-3a), 153.4 (C-7), 151.8 (C-6), 149.0 (C-3', 4'), 146.3 (C-1), 137.4 (C-4), 131.9 (C-4a), 131.7 (C-3), $130.1\left(\mathrm{C}-1^{\prime}\right), 128.8$ (C-8a), $124.7\left(\mathrm{C}-6^{\prime}\right), 120.0(\mathrm{C}-2), 111.7\left(\mathrm{C}-2^{\prime}\right), 109.0$ $\left(\mathrm{C}-5^{\prime}\right), 107.1(\mathrm{C}-5), 107.0\left(\mathrm{C}-1^{\prime \prime}\right), 102.9(\mathrm{C}-8), 102.6\left(\mathrm{OCH}_{2} \mathrm{O}\right), 74.4\left(\mathrm{C}-3^{\prime \prime}\right)$, $72.8\left(\mathrm{C}-2^{\prime \prime}\right), 69.7\left(\mathrm{C}-4^{\prime \prime}\right), 69.2(\mathrm{C}-2 \mathrm{a}), 67.6\left(\mathrm{C}-5^{\prime \prime}\right), 56.0\left(7-\mathrm{OCH}_{3}\right), 56.8(6-$ $\mathrm{OCH}_{3}$ ).

Cytotoxicity Assays The human epidermoid carcinoma (KB), the mouse leukaemia (P-388), the human hepatoma cell (Hep G2), the human hepatoma cell trans fected HDV (Hep 2,2,15) were from American Type Culture Collection. All cell lines were propagated in RPMI-1640 medium supplement with $10 \%(\mathrm{v} / \mathrm{v}) \mathrm{FBS}, 100 \mathrm{U} / \mathrm{ml}$ penicillin and $100 \mu \mathrm{g} / \mathrm{ml}$ streptomycin at $37{ }^{\circ} \mathrm{C}$ in a humidified atmosphere of $5 \% \mathrm{CO}_{2}$ and $95 \%$ air.

The cell viability was determined by the MTT assay. $5 \times 10^{3}$ cells were plated in 96-well microtiter plates and treated with the various concentrations of test samples for different indicated times. At the end of each time point, $100 \mu \mathrm{l}$ of MTT $(0.5 \mathrm{mg} / \mathrm{ml})$ were added to each well after removing the growth medium. The plates were then incubated at $37^{\circ} \mathrm{C}$ for $1 \mathrm{~h}$, allowing viable cells to reduce the yellow tetrazolium salt into dark blue formazan crystals. At the end of the $1 \mathrm{~h}$ incubation, the MTT solution was removed, and $100 \mu \mathrm{l}$ of DMSO were added to each well to dissolve the formazan crystals. The absorbance in individual well was determined at the absorbance at $550 \mathrm{~nm}$. All of the experiments were plated in triplicate, and the $\mathrm{IC}_{50}$ is the concentration of agent that reduced cell growth by $50 \%$ under the experimental conditions.

Acknowledgement We cordially thank Prof. Yang-Chang Wu, Graduate Institute of Natural Products, Kaohsiung Medical University, for the tested cytotoxic assay. This work was financially supported by a grant (NSC 85 2113-M-273-001) of the National Science Council of R.O.C.

\section{References}

1) Hsieh C. F., Chaw S. M., Wang J. C., "Flora of Taiwan," 2nd ed., Vol. 3, Editorial Committee of the Flora of Taiwan, Taipei, Taiwan, ROC, 1993, p. 496.

2) Youkwan J., Srisomphot P., Sutthivaiyakit S., J. Nat. Prod., 68, 10061009 (2005).

3) Tanaka R., Matsunaga S., Phytochemistry, 27, 2273-2277 (1988).

4) Houghton P. J., Woldermariam T. Z., O'shea S., Thyagarajan S. P., Phytochemisry, 43, 715-718 (1996)

5) Huang Y. L., Chen C. C., Hsu F. L., Chen C. F., J. Nat. Prod., 61, 1194-1197 (1998).

6) Sutthivaiyakit S., Na Nakorn N., Kraus W., Sutthivaiyakit P., Tetrahedron, 59, 9991—9996 (2003)

7) Torben L. B., Felipe G., Kurt B. G. T., Phytochemistry, 33, 189-191 (1993).

8) Uin M. T., Lee S. S., Liu K. C. S. C., J. Nat. Prod., 58, 244-249 (1995).

9) Zhang Y. T., Abe T., Tanaka T., Yang C. R., Kouno I., J. Nat. Prod., 64, 1527-1532 (2001)

10) Ishimaru K., Yoshimatsu K., Yamakawa T., Kamada H., Shimomura K., Phytochemistry, 31, 2015-2018 (1992).

11) Zhang Y. T., Nagao T., Tanaka T., Yang C. R., Okabe H., Kouno I., Biol. Pharm. Bull., 27, 251-255 (2004).

12) Miguel O. G., Calixto J. B., Sanntos A. R. S., Messana I., Ferrari F., Filho V. V., Pizzolatti M. G., Yunse R. A., Planta Med., 64, 146-149 (1996).

13) Kan W. S., "Manual of Medicinal Plants in Taiwan," Vol. 3, National Research Institute of Chinese Medicine Taiwan, Republic of China, 1985, pp. 439-443.

14) Fukamiya N., Lee K. H., J. Nat. Prod., 49, 348-350 (1986).

15) Evcim U., Gözler B., Freyer A. J., Shamma M., Phytochemistry, 25, 1949-1951 (1986).

16) Chen C. Y., Chang F. R., Teng C. M., Wu Y. C., J. Chin. Chem. Soc., 46, 77-86 (1999).

17) Wu T. S., Hwang C. C., Kuo P. C., Kuo T. H., Damu A. G., Su C. R., Chem. Pharm. Bull., 52, 1227-1230 (2004).

18) Wu T. S., Ou L. F., Teng C. M., Phytochemistry, 36, 1063-1068 (1994).

19) Kuo P. C., Chiu C. C., Shi L. S., Li C. Y., Wu S. J., Damu A. G., Wu P. L., Kuo C. S., Wu T. S., J. Chin. Chem. Soc., 49, 113-116 (2002).

20) Ulubelen A., Mericli A. H., Mericli F., Kaya U., Phytochemistry, 37, $1600-1601$ (1994)

21) Watanabe K., Mimaki Y., Sakagami H., Sashida Y., Chem. Pharm. Bull., 50, 121-125 (2002). 